\title{
Environmental and Health Concerns Associated with the Open Dumping of Municipal Solid Waste: A Lagos, Nigeria Experience
}

\author{
Adeolu O. Aderemi ${ }^{1, *}$, Tope C. Falade ${ }^{2}$ \\ ${ }^{1}$ Ecotoxicology Laboratory, Department of Zoology, University of Lagos, Akoka, Lagos, 23401, Nigeria \\ ${ }^{2}$ Department of Built and Natural Environment, University of Central Lancashire, PR1 2HE, UK
}

\begin{abstract}
Landfill is the simplest and most commonly used method of disposing municipal solid waste (MSW). In Nigeria, they are better categorized as open dumps, sited for convenience and usually involve the pitching of waste in pre-e xisting pits. In Lagos, the most populated city in Nigeria, most of these open pits are located near residential quarters and therefore pose a threat to public health and the environment. The absence of containment systems at the sites allows the possible percolation of leachate into groundwater. In addition, the methane gas generated as a result of bacterial degradation of waste is not collected and poses a potential fire hazard. The sites harbour nu merous scrap tyres which not only fuel the fires but are also breeding grounds for disease transmitting vermin. Landfill fires especially those involving tyres emit dioxin which can cause reproductive impairment and cancer in humans at extremely low concentrations. Scavenging birds at these sites are potential carriers of diseases. This paper examines the potential environmental and health risks posed by some unsanitary MSW landfills in Lagos, Nigeria and calls for the need to start adopting modern waste management practices to ensure the protection of public health and the environment.
\end{abstract}

Keywords Municipal Solid Waste, Landfill, Vermin, Odour, Landfill Fire, Leachate

\section{Introduction}

Landfill remains the simplest and the most commonly used method for disposing municipal solid waste[4]. In most low to medium income developing nations like Nigeria, almost 100 percent of generated waste goes to landfills[17]. In spite of the recycling and composting of g reater amounts of municipal solid waste (MSW) in the United States in the last forty years, the majority of MSW generated still end up in landfills[16].

While wastes are disposed in open dumps in developing nations; these have become obsolete and historical in the developed countries. Sanitary landfills which are wellengineered facilities (with liners, leachate collection/ treatment system, and gas collection system) are now used to ensure the protection of human health and the environment. These modern landfills are regulated under strict federal and state regulations and are therefore specially sited, designed, operated, monitored, closed, and cared for after closure to ensure environmental performance[16]. However, it is different in Nigeria, where the unsanitary landfills are not

* Corresponding author:

bodeoludunks@yahoo.com (Adeolu O. Aderemi)

Published online at http://journal.sapub.org/ajee

Copyright (C) 2012 Scientific \& Academic Publishing. All Rights Reserved subject to strict regulations, and are usually sited for convenience, such as the presence of a pre-existing hole (created from sand mining activities) into which waste could be deposited[17].

According to Daskalopoulous et al.[9], landfilling in developing countries typically involves pitching refuse into a depression or closed mining site. In Lagos, Nigeria, some of these open pits are located near residential housing and therefore represent a threat to human health and the environment. This paper attempts to identify the potential health and environmental hazards posed by some unlined municipal solid waste landfills in Igando area of Lagos metropolis, Nigeria.

\section{Landfill Gas Emissions}

Landfill gas is generated during the natural process of anaerobic bacterial decomposition of organic material contained in municipal solid waste (MSW) landfills. The quantity of gas that a MSW landfill generates and its components are influenced by the type and age of the waste buried in the landfill, the quantity and types of organic compounds in the waste, and the moisture content and temperature of the waste[22]. Landfill gas by volume is about 40-60 percent methane and 40-60 percent carbon dio xide. It also contains small a mounts of nitrogen, sulphide, 
oxygen, hydrogen, and less than 1 percent non-methane organic compounds (NMOCs)[18].

\section{Description of the Study Area}

\subsection{Climate}

The climate of Lagos, including that of the study area is tropical with an annual rainfall of approximately $1408 \mathrm{~mm}$ (57.7 inches). Eighty percent of the annual rainfall $(1160 \mathrm{~mm})$ falls during the south west monsoon, (April-October) and the remaining twenty percent $(250 \mathrm{~mm})$ falls during the northeast monsoon (November-March). The air is very humid throughout the year, with monthly average temperatures ranging from $28^{\circ} \mathrm{C}$ in July/August to $32^{\circ} \mathrm{C}$ in February/March.

\subsection{Study Sites}

The Soluos landfills are located at the extreme east-west area of metropolitan Lagos in Alimosho Local Government

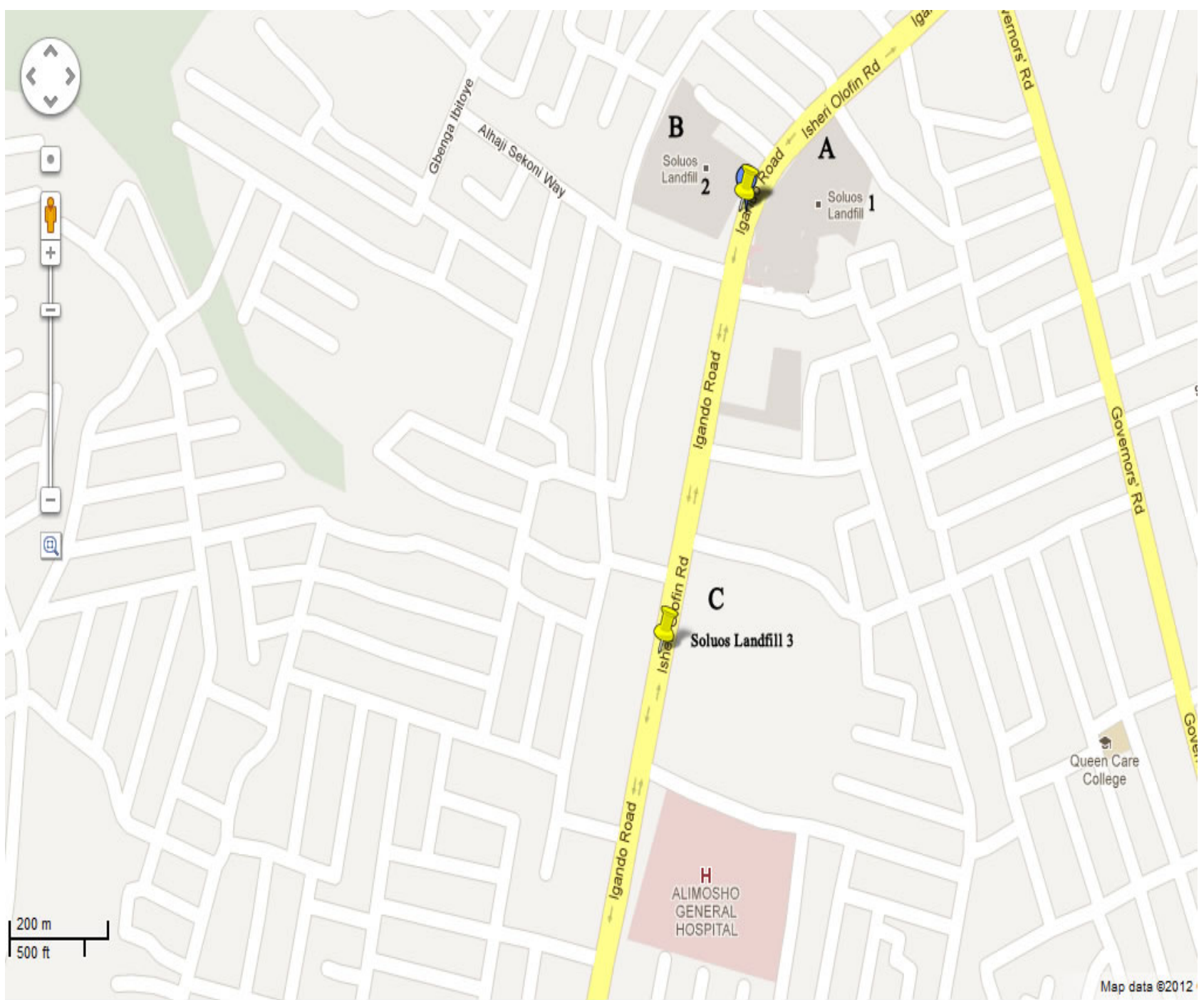

(Figure 1). They are among the five active landfills currently operated by Lagos Waste Management Authority (LAWMA). In its monthly report, it was reported that Soluos 2 and 3 landfills received 81,388 metric tonnes of MSW out of a total of 239,282 metric tonnes landfilled in December, 2011[27]. They receive waste from the entire Lagos metropolis and wastes are of different types, from do mestic, commercial, and industrial sources. The sites are originally burrow pits for lateritic soil, unlined and bordered by residential housing (Figure 2). The wastes brought by trucks are dumped haphazardly without the use of daily soil cover and are sorted by the on-site waste pickers.

\subsubsection{Soluos (1) Landfill (A)}

It encompasses an area of 7.5 hectares and located on $\mathrm{N}^{0} 6^{0} 34.307^{\prime}, \mathrm{E}^{2} 03^{0} 15.211^{\prime}$. It is the oldest of the sites. It began operation in 1993 and closed in 2006 without the use of a final cap or cover. It was reopened in 2011 and has since been receiving wastes.

Figure 1. Location of Soluos landfills (A-C) in Igando area of Lagos, Nigeria 


\subsubsection{Soluos (2) Landfill (B)}

The site $\left(\mathrm{N}^{0} 6^{0} 34.286^{\prime}, \mathrm{E}^{\circ} 03^{0} 15.146^{\prime}\right)$ spreads over an area of 7.8 hectares and is almost filled up. It started operation in 2008 and on an average about $2,250 \mathrm{~m}^{3} /$ day of waste is dumped at the site.

\subsubsection{Soluos (3) Landfill (C)}

This site $\left(\mathrm{N}^{0} 6^{0} 33.897^{\prime}, \mathrm{E} 003^{0} 15.082^{\prime}\right)$ started operation in 2008 and is estimated to receive about $2,250 \mathrm{~m}^{3}$ in a day.

It is divided into cells with access roads. It is the largest of the three sites, spreading over an area of 12 hectares with a large portion of it yet to be filled up. It is flanked by a government hospital (Figure 1)

\section{Odour Nuisance}

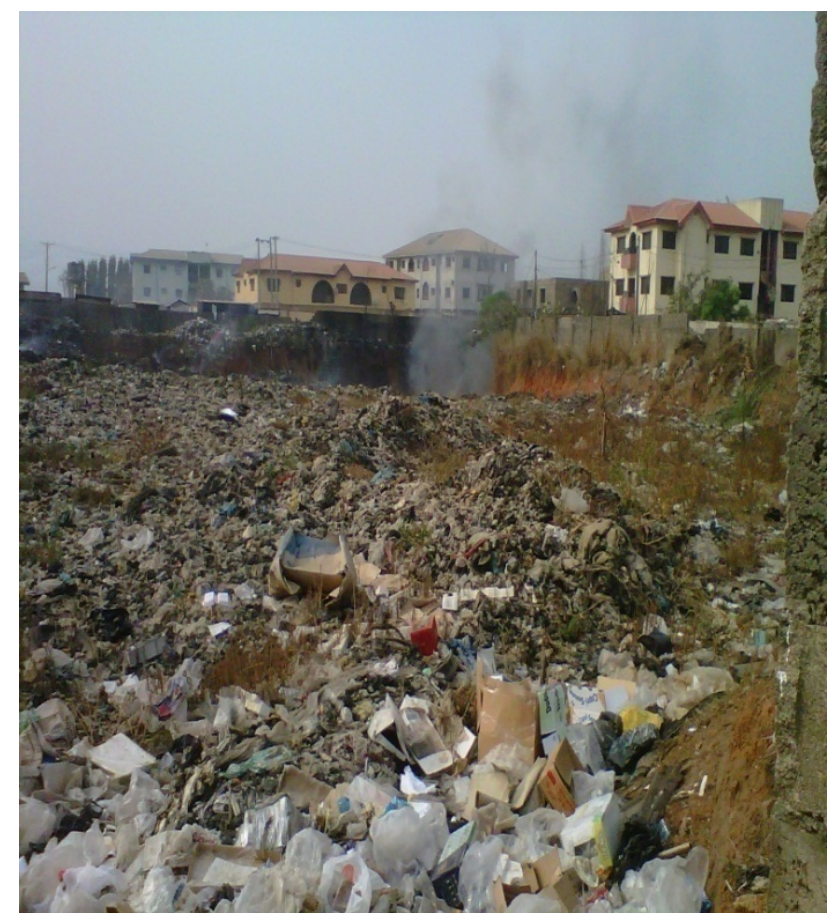

Figure 2. Soluos (2) landfill within residential housing in Lagos, 2012

The Soluos landfills lack gas collection systems and as a result the landfill gas produced is discharged freely into the air. One of the concerns related to uncontrolled landfill gas emissions is their unpleasant odour. Landfill gas odours are produced by bacterial or chemical processes and can emanate from both active and closed landfills. These odours can migrate to the surrounding community[3]. Compounds found in landfill gas are associated with strong, pungent odours. Potential sources of landfill odours include sulphides, ammonia and certain NMOCs, if present at concentrations that are high enough. Of these gases, hydrogen sulphide is emitted from landfills at the highest rates and concentrations [3]. These unpleasant odours can lower the quality of life for individuals that live near landfills and potentially reduce local property values[23]. Many people may find the odours emitted from a landfill offensive or unpleasant. In reaction to the odours, some people may experience nausea or headaches. Although such responses are undesirable, medical attention is usually not required. Although landfill odours may not be associated with long-term adverse health effects or illness for most people, the added disruption and stress of day-to-day activities can greatly impact quality of life[3].

\section{Spread of Diseases by Vermin}

According to Christopoulos[6], a landfill is an artificial isolated biotope with its own characteristics. The abundant food, the coverage as well as the high temperatures at landfills attract vermin such as birds, rats or rodents, as well as numerous species of insects (flies and mosquitoes) which are potential transmitters of serious illnesses and diseases. Birds that defaecate and carry waste off-site may cause nuisance, health and amenity hazards to local residents [26].

Cattle egrets (Bubulcus ibis), species of heron are ubiquitous on landfills in Nigeria (Figure 3). Cattle egrets have been implicated in the spread of animal infections such as infectious bursal disease[10] and possibly Newcastle disease[11]. Insect/mosquito breeding in stagnant water pools on waste sites and in canals and scrap tyres which are reservoirs of rain water can result in the spread of disease to site workers, waste pickers and neighbouring residents[19].

The abundance of waste tyres on the sites (Figure 4.) is also a serious concern. Tyres are ideal sites for rodents and also breeding sites for mosquitoes that transmit malaria, dengue and yellow fever. The round shape of tyres, coupled with their impermeability, enables them to hold water and other debris (decaying leaves) for long period of time, turning them into perfect sites for the development of mosquito larvae[19]. Salmonellosis, ornithosis, rat bite fever, leptospirosis, and eastern aquine encephalitis are among some of the important vermin diseases that affect humans [15].

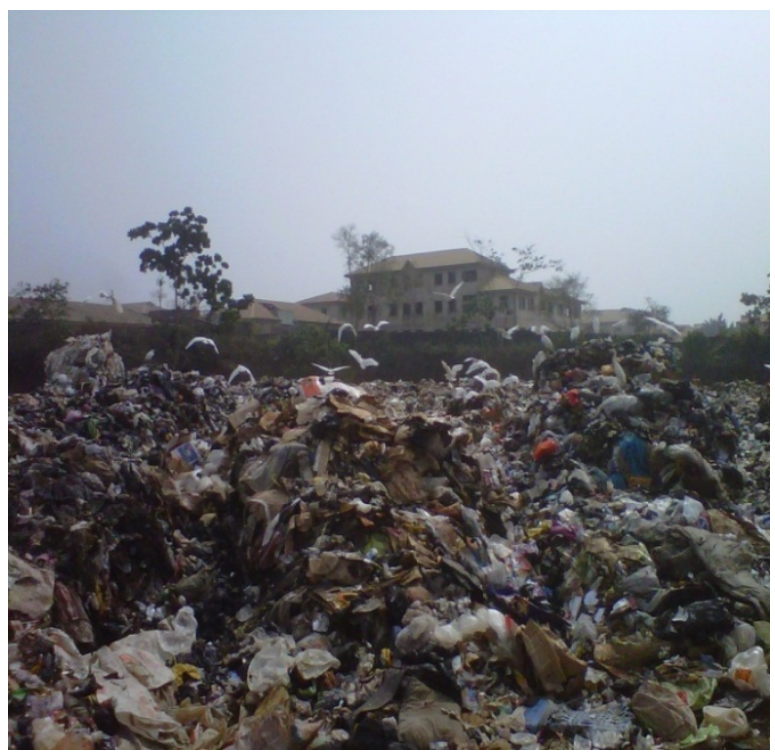

Figure 3. Cattle egrets foraging on Soluos (1) landfill, 2012 


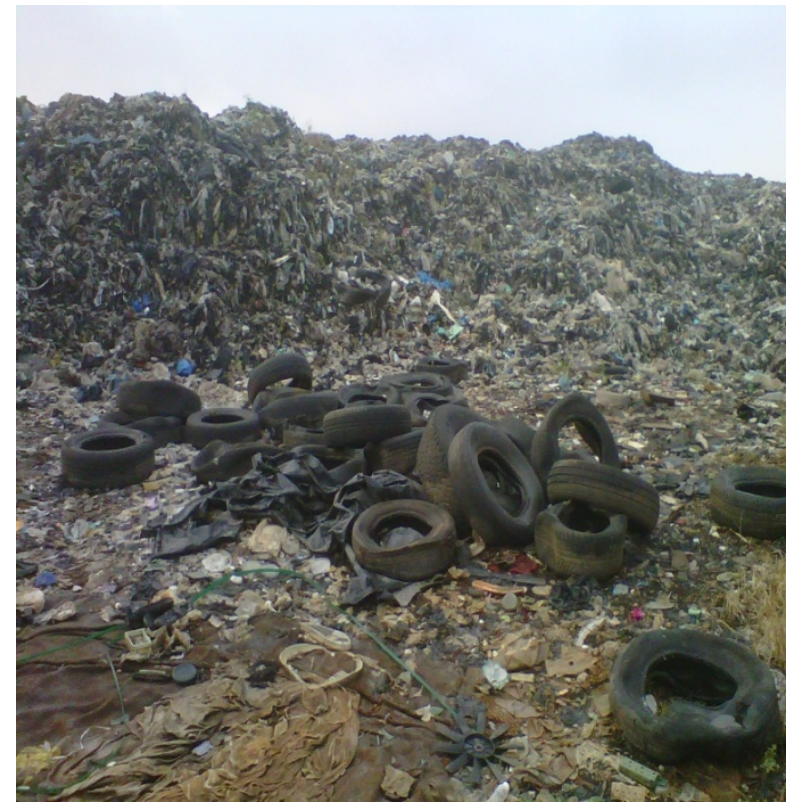

Figure 4. Scrap tyres on Soluos (2), february 2012

\section{Leachate Seepage into Groundwater}

Leachate is a high-strength wastewater formed as a result of percolation of rain-water and moisture through waste in landfills[12]. Municipal landfill leachate are highly concentrated complex effluents which contain dissolved organic matters; inorganic compounds such as ammonium, calcium, magnesium, sodium, potassium, iron, sulphates, chlorides and heavy metals such as cadmium, chromium, copper, lead, zinc, nickel; and xenobiotic organic substances [13],[5].

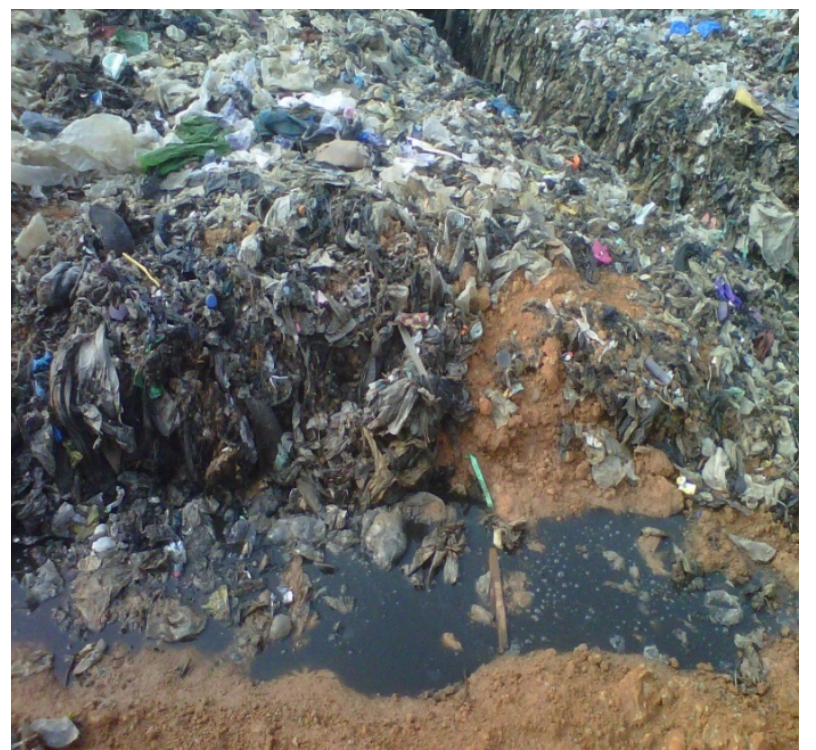

Figure 5. Leachate collects at the base of a waste cell on Soluos (3), 2012

Landfill Leachate contains various contaminants and toxic substances especially heavy metals which can migrate, infiltrate and descend in the soil profile to contaminate the adjacent surface water and groundwater[7]. This poses a serious health risk to those who rely on it for do mestic water supply. The threat posed is high in the study area as the landfills are improperly sited, unsealed, and lack leachate collection systems, thus allowing uncontrolled downward flow of leachate into groundwater and/or its accumulation below the landfills (Figure 5). The contamination of groundwater by leachate from Soluos (2) landfill has been reported in literature[14],[1]. According to[1], high levels of $\mathrm{Na}^{+}$, total dissolved solids (TDS) and electrical conductivity (EC) above the World Health Organization's (WHO) tolerance levels for drinking water were observed in 37.5, 62.5 , and $100 \%$ of the groundwater samples respectively.

\section{Landfill Fire}

The environment is threatened by landfill fires through the toxic pollutants emitted into the air, water, and soil. They also pose a risk to firefighters and residents who are exposed to the hazardous chemical co mpounds they emit. Incidents of fires on Soluos (2) landfill have been recently reported[2].

Of particular concern on some of the Soluos sites are long smouldering fires that tend to smoulder for weeks to months at a time. This can cause a build up of the by-products of combustion in confined areas such as landfill site buildings and surrounding homes (Figure 6), which adds an additional health hazard[25].

A common cause of these landfill fires is spontaneous combustion. This results from an increase in the oxygen content of the landfill, which increases bacterial activity and raises temperatures (aerobic decomposition). These so-called "hot spots" can come into contact with pockets of methane gas and result in a fire. This can be identified when white or brown s moke emanates from some part the of the landfill surface[24]. The heat from the fire can cause chemi cals to volatilize or breakdown and enter the environment through the smoke. Burning tyres emit dioxins [20],[8] which can cause cancer and reproductive impairment at extremely low levels[21].

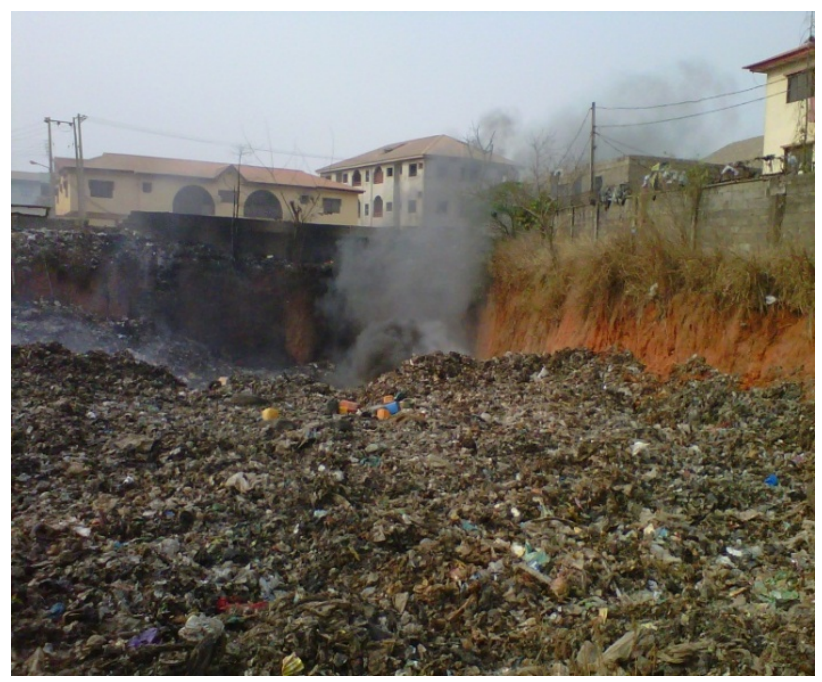

Figure 6. Smoke from fire involvingtyres on Soluos (2) drifting to nearby homes, 2012 


\section{Conclusions}

The Soluos landfills will continue to represent a threat to the surrounding residential housing including the nearby hospital for many years, even after closure. It is necessary to identify the hazards they pose, assess the risks fromexposure to them and eliminate or reduce such risks to as low as reasonably practicable. This paper examines the potential hazards. It calls for the relevant environmental agencies to make modern and sustainable waste management practices a high priority to ensure the protection of public health and the local environment.

\section{REFERENCES}

[1] Aderemi O. Adeolu, Oriaku A. Victoria, Adewumi A. Gbenga, Otitoloju A. Adebayo, “Assessment of Groundwater Contamination by Leachate near a Municipal Solid Waste Landfill”, African Journal of Environmental Science and Technology, vol.5, no.11, pp.933-940, 2011.

[2] Aderemi O. Adeolu and Otitoloju A. Adebayo, "An Assessment of Landfill Fires and Their Potential Health Effects: A Case Study of a Municipal Solid Waste Landfill in Lagos, Nigeria”, World Academic Publishing, International Journal of Environmental Protection, vol.2, no.2, pp. 22-26, 2012.

[3] ATSDR, Agency for Toxic Substances and Disease Registry (2001), Landfill gas primer: Landfill gas safety and health issues.[Online] Available: http://www.atsdr.cdc.gov/hac/land fill/html/ch3.html.

[4] A. Barrett and J. Lawlor, "The Economics of waste management in Ireland", Economic and Social Research Institute, Dublin, 1995.

[5] Christensen T.H., Kjeldsen P., Bjerg P.L., Jensen D.L., Christensen J.B. and Baun A, "Biogeochemistry of landfill leachate plumes”, Applied Geochemistry, vol.16, pp. 659718, 2001.

[6] P.G. Christopoulos, "Waste treatment in Greece after the passage of EU landfill directive: Landfill bioreactor cell treatment as sustainable solution”, M. Env. Sci. thesis, Lund University, Sweden, 2005.

[7] Chuangcham U., Lertsirivorakul R., Charusiri P. and Wirojan agud W, Hydrogeological Asessment of the Kha Ban Landfll Site, Ban Kam Bon, Muang District, Khon Kaen Province, NE Thailand. "Hydrogeological assessment of the Kha Ban landfill site, Ban Kam Bon, Muang District, Khon Kaen Province, NE Thailand”, (In Wannakao et al.In Wannakao, et al (Eds.), Proceedings of International Conference on geology, geotechnology, mineral research of Indochina, pp. 253-258, 2005.

[8] 28-30 November, 2005, Kosahotel, Khon Kaen, Thailand, p.CIWMB, California Integrated Waste Management Board (1992), Tires as a fuel supplement: Feasibility study.[Online] Available: http://www.calrecy cle.ca.gov/publications/Tires/ 40193001.pdf

[9] Daskalopoulous E., Badr O. and Probert S.D, “An Integrated
Approach to Municipal Solid Waste Management”, Resources, Conservation and Recycling, vol.24, no.1, pp. 33-50, 1998.

[10] Fagbohun O.A., Owoade A.A., Oluway elu D.O. and Olay emi F.O, "Serological Survey of Infectious Bursal Disease Virus Antibodies in Cattle Egrets, Pigeons, and Nigerian Laughing Doves", African Journal of Biomedical Research, vol.3, no.3, pp.191-192, 2000a.

[11] Fagbohun O.A., Oluway elu D.O., Owoade A.A. and Olay emi F.O, " Survey for Antibodies to Newcastle Disease Virus in Cattle Egrets, Pigeons, and Nigerian Laughing Doves”, African Journal of Biomedical Research, vol.3, pp.193-194, 2000b.

[12] Hasar H., Unsal S. A., Ipek U., Karatas S., C nar O., Yaman C. and K nac C., "Stripping/ flocculation/ membrane bioreactor/ reverse osmosis treatment of municipal landfill leachate", Journal of Hazardous Materials, vol.171, pp. 309-317, 2009.

[13] G.F. Lee and A. Jones-Lee, “Groundwater quality protection: A suggested approach for water utilities", Report to the CA/NV AWWA Section Source Water Quality Committee, 1993.

[14] Longe E.O. and Balogun M.R., "Groundwater Quality Assessment near a Municipal Landfill, Lagos, Nigeria. Research Journal of Applied Sciences, Engineering and Technology, 2(1), 39-44, 2010.

[15] R.G. McLean, Wildlife Diseases and Humans, Oxford: Blackwell publishing Ltd, 1994.

[16] NSWMA, National Solid Waste Management Association (2011), Solid waste technologies, regulations and issues: municipal solid waste landfills.[Online] Available: http:// www.environmentalistsevery day.org/issues-solid-waste-tech nologies-regulations/landfills-garbage-disposal/index.php.

[17] Taylor R. and Allen A., "Waste disposal and landfill: Potential hazards and information needs", In WHO, World Health Organization (Eds.), Protecting groundwater for health: Managing the quality of drinking water resources, pp. 339-360, 2006.

[18] G. Tchobanoglous, H. Theisen and S.A. Vigil, Integrated solid waste management: Engineering principles and management issues, New York: McGraw-Hill, 1993.

[19] UNEP, United Nations Environmental Programme, “Revised technical guidelines on the environmentally sound management of used tyres", Paper presented on the $9^{\text {th }}$ meeting of the Conference of the Parties to the Basel Convention on the Control of Transboundary Movements of Hazardous waste and their Disposal, Bali, 2008.

[20] USEPA, United States Environmental Protection Agency, "Questions and answers about dioxins", EPA Tech. Rep., 2000.

[21] USEPA, United States Environmental Protection Agency, "Dioxin reassessment" National Academy of Science review draft, Washington DC, EPA/600/P-00/001Cb, 2004.

[22] USEPA, United States Environmental Protection Agency (2008a), Frequent questions: Landfill gas. Landfill Methane Outreach Programme, [Online] Available: http://www.epa. gov/lmop/faq/landfill-gas.html

[23] USEPA, United States Environmental Protection Agency (2008b), Frequent questions: Public health, safety and the 
environment. Landfill Methane Outreach Program,[Online] Available: http:/www.epa.gov/lmop/faq/public.html.

[24] USFA, United States Fire Administration (2001), Topical fire research series: Landfill fires,[Online] Available: http:// www.usfa.dhs.gov/download/pdf/tfrs/v1i18-508.pdf

[25] USFA, United States Fire Administration, “Landfill fires, their magnitude, characteristics and mitigation”, TriData
Corporation, Arlington, Virginia, Tech. Rep. FA-225, 2002.

[26] W. Watson and V. Hack, "Wildlife management and habitat creation on landfill sites: a manual of best practice”, Ecoscope Applied Ecologists, Muker, United Kingdom, 2000.

[27] LAWMA (2011), Summary of refuse deposited for the month of December 2011,[Online] Available: http://www.lawma. gov.ng/landfilldata/December_2011.pdf 